\title{
Strategi Penurunan Pencemaran Limbah Domestik di Sungai Code DIY
}

\author{
Widodo B. ${ }^{1)}$; Kasam ${ }^{1)}$; Ribut $\mathrm{L}^{2)}$ dan Ike A. ${ }^{3)}$ \\ ${ }^{1)}$ Jurusan Teknik Lingkungan, Fakultas Teknik Sipil dan Perencanaan, Universitas Islam Indonesia; \\ ${ }^{2)}$ Pusat Studi Perubahan Iklim dan Kebencanaan (PuSPIK), UII \\ ${ }^{3)}$ Fakultas Psikologi, UII \\ Email: widodo.bronto@uii.ac.id; widodo_indo@yahoo.com
}

\begin{abstract}
Abstrak
Kualitas air sungai terutama yang terletak di kawasan urban saat ini kondisinya semakin memprihatinkan. Upaya mengatasi permasalahan pencemaran air yang paling efektif adalah mencegah masuknya bahan pencemaran ke dalam badan air. Penelitian ini bertujuan untuk menganalisis tingkat pencemaran limbah dometik, menganalisis potensi pencemar air yang masuk ke Sungai Code, serta menganalisis strategi pengelolaan Sungai Code untuk menurunkan beban pencemaran yang masuk dari sumber domestik. Pengambilan sampel air limbah untuk uji laboratorium dari sumber pencemar domestik untuk 12 IPAL komunal. Parameter yang dianalisis antara lain COD, TSS, dan NH. Penentuan responden didasarkan pada pendekatan penentuan sampel secara acak pada wilayah tertentu (area random sampling). Analisis Data terdiri dari analisa pencemaran limbah domestik, analisis potensi sumber pencemar, serta analisis strategi penurunan bebab pencemaran. Hasil penelitian menunjukkan kondisi yang baik, dimana konsentrasi outlet lebih rendah daripada inlet antara lain untuk COD di titik 2,3,4, dan 8, TSS di titik 2,3,4,5,6,11, dan 12 serta untuk $\mathrm{NH}_{3}$ di titik 2,3,4,8, dan 9. Artinya, IPAL pada titik selain itu perlu dicek kembali optimalisasi fungsinya. Strategi sosial penurunan pencemaran limbah domestik antara lain dengan pemberdayaan masyarakat, penguatan komunitas lokal, serta optimalisasi kelembagaan formal.
\end{abstract}

Kata Kunci : Limbah Domestik, Strategi Penurunan, Sungai Code, Yogyakarta

\section{PENDAHULUAN}

Semakin meningkatnya aktivitas pembangunan ekonomi, perubahan tata guna lahan dan meningkatnya pertumbuhan penduduk mengakibatkan tingginya tekanan terhadap lingkungan. Sungai sebagai bagian lingkungan hidup saat ini kondisinya memprihatinkan, terjadi kecenderungan perubahan ekosistem sungai yang ditunjukkan dengan degradasi kuantitas dan kualitas air.

Hampir sebagian besar daerah aliran sungai di Indonesia mengalami kerusakan, dari 82 sungai besar di Indonesia 62 diantaranya tergolong dalam sungai yang kritis (BBWS Serayu Opak, 2008). Sebagian besar kerusakan sungai diakibatkan oleh aktivitas manusia yang mengibaratkan sungai sebagai tempat pembuangan sampah dan limbah gratis. Segala macam limbah dan kotoran dibuang ke sungai tanpa ada pengolahan lebih dahulu. Sungai-sungai yang melewati kota besar pada umumnya kualitas airnya tercemar oleh limbah baik dari industri, rumah tangga, perikanan, dan pertanian. Dampak yang ditimbulkan dari segi kesehatan sangat berbahaya, karena air sungai masih dipergunakan untuk keperluan sehari-hari baik mandi, mencuci ataupun untuk air minum. Polusi air juga akan mengancam habitat ikan di sungai. Sungai yang tercemar dari segi estetika juga tidak nyaman, selain berwarna hitam, banyak sampah yang terapung, juga baunya menyengat. 
Sungai Code menjadi pusat perhatian banyak pihak dan memiliki tingkat kemendesakan dalam pengelolaannya. Sungai Code melintasi Kota Yogyakarta dan berdekatan dengan beberapa tempat strategis, seperti Malioboro, Tugu, Kraton, dan lainnya. Sungai Code melintas pada kawasan pemukiman yang cukup padat di kiri kanan sungai serta kondisinya menunjukkan kecenderungan makin memburuk dari tahun ke tahun.

Seiring dengan meningkatnya laju pertumbuhan penduduk kawasan Sungai Code pun menjadi sasaran untuk dijadikan daerah permukiman. Akibatnya permasalahan di daerah aliran Sungai Code pun menjadi sangat kompleks. Mulai terjadinya pencemaran air sungai, penyempitan badan sungai, tingginya erosi dan sedimentasi, hingga berujung pada seringnya terjadi banjir di daerah aliran Sungai Code. Sungai Code menunjukkan kualitas air terburuk, dibandingkan sungai lainnya yang melintas di Kota Yogyakarta, karena bakteri Coliform Tinja terdeteksi paling tinggi dan kandungan oksingen terlarut paling rendah.

Upaya mengatasi permasalahan pencemaran air yang paling efektif adalah mencegah masuknya bahan pencemaran ke dalam badan air. Sebagai langkah awal merumuskan upaya tersebut, informasi tingkat pencemaran, potensi sumber pencemar serta kondisi karakteristik psikologi dan sosial penduduk perlu tersedia secara baik dan komprehensif. Penelitian ini akan menganalisis berdasarkan data-data tersebut guna merumuskan strategi penurunan beban pencemar yang optimal sesuai dengan karateristik penduduk di kawasan Sungai Code.

\section{METODE PENELITIAN}

Pengambilan sampel air limbah untuk uji laboratorium dari sumber pencemar domestik untuk 12 IPAL komunal. Parameter yang dianalisis antara lain COD, TSS, dan $\mathrm{NH}_{3}$. Pengambilan sampel air dilakukan untuk dianalisis baik secara langsung di lapangan maupun di laboratorium berdasarkan Peraturan Pemerintah No. 82 Tahun 2001 tentang Pengelolaan Kualitas Air dan Pengendalian Pencemaran Air serta Peraturan Menteri Lingkungan Hidup Nomor 01 Tahun 2010 tentang Tata Laksana Pengendalian Pencemaran Air. Penentuan responden didasarkan pada pendekatan penentuan sampel secara acak pada wilayah tertentu (area random sampling). Lokasi sampel responden ditentukan di daerah Cokrodiningratan RT 37 RW 08 dengan jumlah responden $21 \mathrm{KK}$ (dari $43 \mathrm{KK}$ yang ada).

Analisis Data terdiri dari analisa pencemaran limbah domestik, analisis potensi sumber pencemar, serta analisis strategi penurunan bebab pencemaran. Pertama, Analisis Pencemaran Limbah 
Domestik dilakukan dengan pengukuran dan uji laboratorium air limbah domestik untuk parameter COD, TSS, dan $\mathrm{NH}_{3}$. Sampel dilakukan pada titik inlet dan outlet limbah. Hasil uji laboratorium selanjutnya dianalisis dengan baku mutu serta membandingkan nilai antara inlet dan outlet. IPAL dinyatakan efektif jika konsentrasi pada outlet sudah lebih rendah dibandingkan inlet untuk suatu parameter. Kedua, Analisis potensi sumber pencemar didasarkan pada hasil pengolahan data kuesioner serta laporan pemantauan dari instansi terkait. Analisis mencakup aspek besaran, frekuensi, proyeksi, jenis serta faktor yang mempengaruhinya. Ketiga Analisis strategi Penurunan Beban Pencemar dilakukan dengan deskriptif. Analisis deskriptif didasarkan pada hasil pengolahan data kuesioner, studi konseptual, studi kebijakan, serta kondisi eksisting. Rekomendasi berupa strategi diletakkan atas prinsip partisipatif dan untuk kepentingan lingkungan.

\section{HASIL DAN PEMBAHASAN}

\section{Beban dan Sumber Pencemaran Limbah Domestik}

Beban pencemaran adalah jumlah suatu unsur pencemar yang terkandung dalam air atau limbah. Besarnya beban pencemaran ini sangat mempengaruhi kualitas air dan dapat menjadi indikator tercemar atau tidaknya suatu perairan. Limbah domestik terdiri dari sampah dan limbah cair. Limbah domestik di DAS Code dibagi menjadi dua kategori yaitu limbah domestik potensial dan riil. Limbah domestik potensial adalah limbah rumah tangga yang limbahnya dibuang pada saluran pembuangan dalam batas DAS sungai, sedangkan limbah domestik riil adalah limbah rumah tangga yang limbahnya dibuang secara langsung ke sungai utama atau melalui saluran air yang langsung mengarah ke sungai utama. Hasil pengukuran terhadap konsentrasi limbah domestik pada inlet dan outlet IPAL sebagaimana tersaji pada gambar berikut.

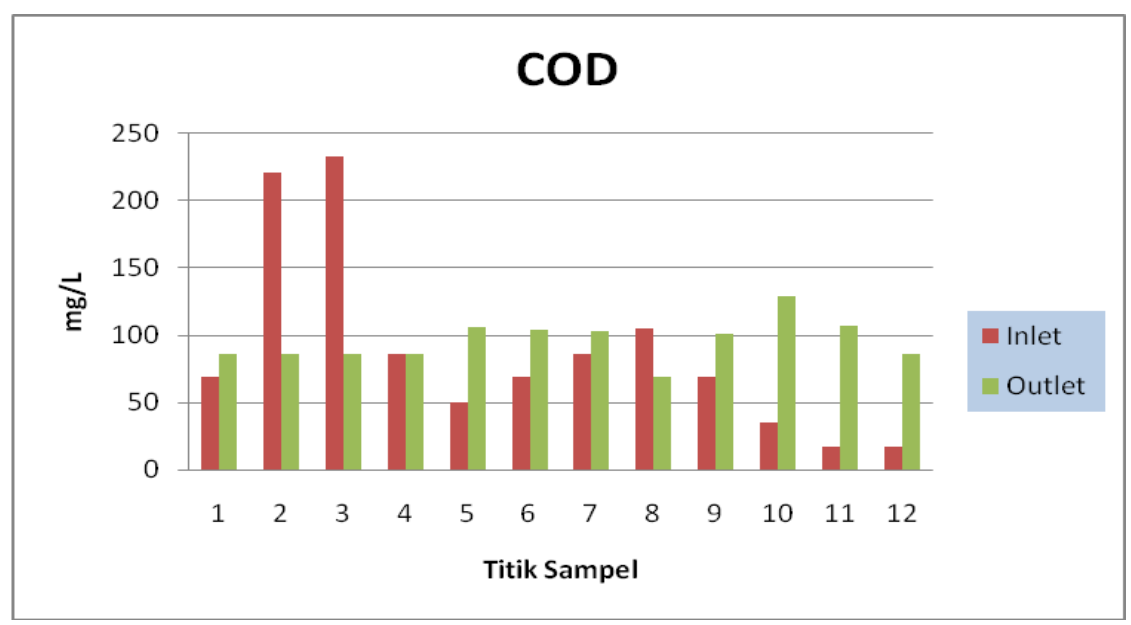

Gambar 1. Perbandingan Konsentrasi COD pada Inlet dan Outlet 


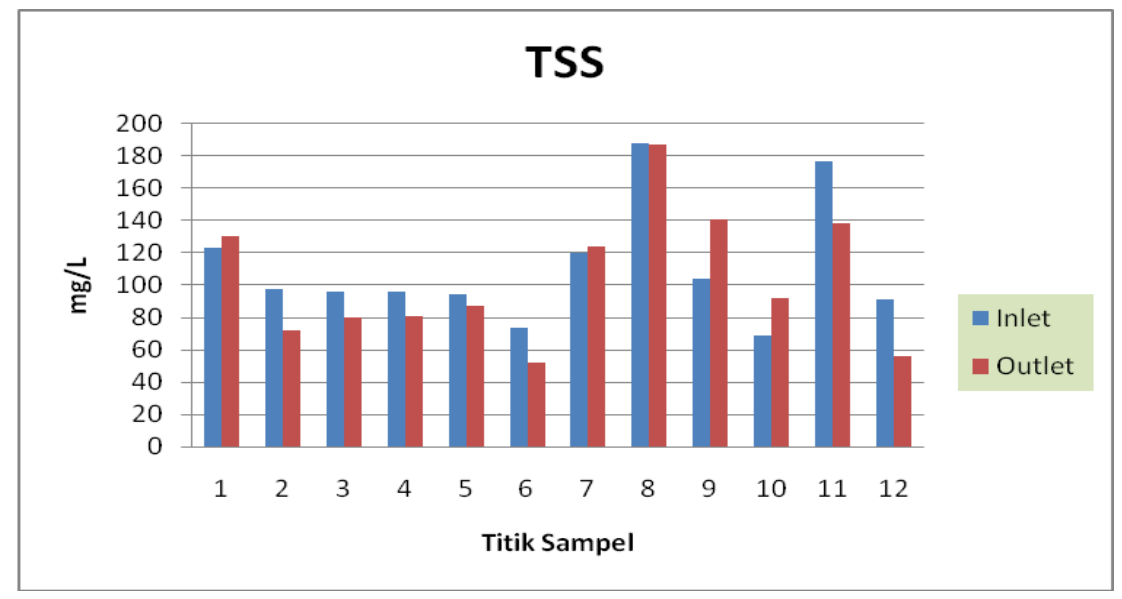

Gambar 2. Perbandingan Konsentrasi TSS pada Inlet dan Outlet

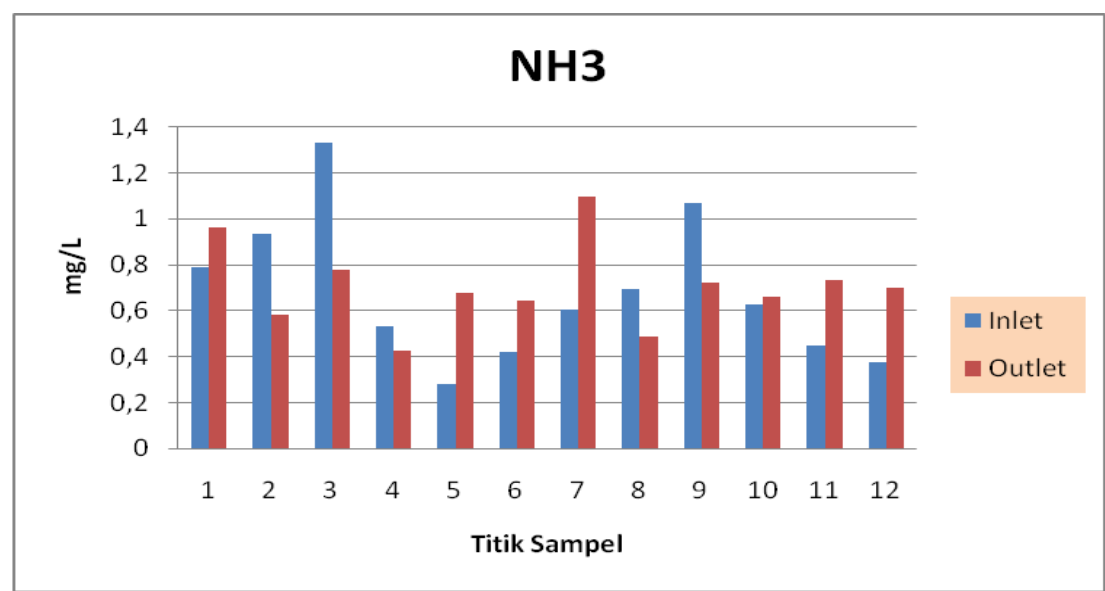

Gambar 3. Perbandingan Konsentrasi $\mathrm{NH}_{3}$ pada Inlet dan Outlet

Berdasarkan grafik di atas kondisi yang baik, dimana konsentrasi outlet lebih rendah dari pada inlet antara lain untuk COD di titik 2,3,4, dan 8, TSS di titik 2, 3, 4, 5, 6, 11, dan 12 serta untuk $\mathrm{NH}_{3}$ di titik 2,3,4,8, dan 9. Artinya IPAL pada titik selain itu perlu dicek kembali optimalisasi fungsinya.

Bahan pencemar domestik dari Sungai Code dapat dibedakan secara umum menjadi beberapa kelompok, yaitu :

1. Bahan pencemar organik, baik yang dapat mengalami penguraian oleh mikroorganisme maupun yang tidak dapat mengalami penguraian.

2. Bahan pencemar anorganik, dapat berupa logam-logam berat, mineral (garam-garam anorganik seperti sulfat, fosfat, halogenida, nitrat)

3. Bahan pencemar berupa sedimen/endapan tanah atau lumpur.

Berdasarkan data survei identifikasi sumber pencemar air dari BLH Provinsi DIY terdapat 214 sumber pencemar di Sub DAS Code yang dapat dilihat rinciannya di Tabel 1. 
Tabel 1. Jumlah dan Jenis Sumber Pencemar di Sub DAS Code

\begin{tabular}{|c|l|c|l|}
\hline No & \multicolumn{1}{|c|}{$\begin{array}{c}\text { Jenis Sumber } \\
\text { Pencemar }\end{array}$} & Jumlah & \multicolumn{1}{|c|}{ Parameter Pencemar } \\
\hline 1. & Pelayanan Kesehatan & 20 & BOD,COD,TSS,NH3,PO4,Minyak \\
\hline 2. & Bengkel/Cuci Motor & 68 & Minyak dan Lemak, pH, Detergen \\
\hline 3. & Industri Batik & 1 & BOD,COD,TSS,Minyak,pH \\
\hline 4. & Industri Tekstil & 1 & $\begin{array}{l}\text { BOD,COD,TSS,Phenol,CR, } \\
\text { Amoniak,Sulfida,pH,Minyak }\end{array}$ \\
\hline 5. & Industri Tahu Tempe & 4 & BOD,COD,TSS,Sulfida,pH \\
\hline 6. & Industri Percetakan & 15 & Pb,biru Metilen,Minyak,pH \\
\hline 7. & Industri Kulit & 3 & $\begin{array}{l}\text { BOD,COD,TSS,CR,NH3,Sulfida, } \\
\text { Minyak,pH }\end{array}$ \\
\hline 8. & Hotel/Restoran/Mall & 90 & $\begin{array}{l}\text { BOD,TSS,Detergen,Minyak dan } \\
\text { Lemak,pH }\end{array}$ \\
\hline 9. & SPBU/Stasiun KA & 10 & Minyak \\
\hline 10. & Peternakan & 2 & $\begin{array}{l}\text { BOD,COD,TSS,Sulfida, } \\
\text { Amoniak,pH }\end{array}$ \\
\hline
\end{tabular}

Sumber: BLH Provinsi DIY Tahun 2012

Sumber pencemar yang mendominasi di Sub DAS Code adalah Hotel/Restoran/Mall, diikuti dengan bengkel/cuci motor dan pelayanan kesehatan. Dari 10 (sebelas) jenis pencemar terdapat 7 sumber pencemar yang menyumbangkan parameter pencemar BOD, COD, TSS. Hal inilah yang menyebabkan hasil BOD, COD melebihi baku mutu. Selain itu dengan keberadaan Industri Percetakan maka ancaman logam berat berpotensi terjadi. Untuk parameter pencemar minyak terdapat di 8 dari 10 jenis pencemar.

\section{Strategi Penurunan Limbah Domestik}

Pencemaran air sungai sebagian besar berasal dari limbah rumah tangga, kemudian industri/usaha. Sistem pengelolaan air limbah dan sanitasi dapat dilakukan dengan :

a) Pengembangan jaringan air limbah komunal, off side, dan on side.

b) Perbaikan sarana sanitasi dasar permukiman, yaitu dengan membuat SPAL (saluran pembuangan air limbah) yang meliputi tanki septik dan sumur peresapan.

c) Pembangunan jamban keluarga maupun komunal termasuk tanki septik komunal, MCK dan WC umum.

d) Pengembangan sistem pengumpulan dan pengolahan lumpur tinja, untuk melayani masyarakat dalam menguras tanki septik. 
e) Perbaikan sarana pengolahan air limbah peternakan dan industri. Air kotor hasil dari limbah peternakan, industri, bengkel, dan sejenisnya harus ditreatment terlebih dahulu sebelum dibuang ke saluran drainase.

Konsep pembuangan air limbah yang onsite dapat dikombinasikan dengan sistem jaringan drainase dan air hujan dalam satu saluran. Sebelum dibuang ke saluran, air limbah diolah melalui Instalasi Pengolahan Air Limbah (IPAL) terutama limbah dari rumah sakit, industri, dan limbah lain yang bisa mencemari lingkungan dan berbahaya bagi kesehatan manusia.

Pengelolaan lingkungan yang berkelanjutan hendaknya memiliki dimensi ekologi, ekonomi dan sosial (Zulkifli, 2003 dalam Widodo et al, 2005). Dimensi ekologi lebih menekankan pada pentingnya upaya-upaya untuk mencegah terganggunya fungsi dasar ekosistem sungai sehingga tidak akan mengurangi fungsi layanan ekologi. Dimensi ekonomi menekankan bahwa pertumbuhan dan efisiensi dalam pemanfaatan sumberdaya alam harus diupayakan secara terus menerus. Dimensi sosial mencakup isu-isu yang berkaitan dengan distribusi kekayaan/pemerataan secara adil serta penghapusan kemiskinan. Berdasarkan konsepsi tersebut maka secara umum pengelolaan Sungai Code dapat dilakukan dengan 3 strategi, yaitu:

a. Pemberdayaan Sosial - Budaya

Ada beberapa isu yang penting diperhatikan dalam pengembangan sektor sosial - budaya yakni (1) upaya meningkatkan kualitas sosial-budaya dalam berkehidupan, (2) mengembangkan konsep pembangunan sosial - budaya yang partisipatif, dan (3) kegiatan pembangunan sosial budaya merupakan proses pembangunan yang berkelanjutan.

b. Pendekatan Politis

Strategi politis lebih dititikberatkan pada institution building. Beberapa hal yang diperlukan dalam strategi politis adalah: (1) Kesiapan aparat pemerintah dalam pembangunan dan pengendalian, baik dari segi kebijaksanaan, dukungan personalia maupun administratif; (2) Kesiapan pihak - pihak lain dalam menghadapi kemungkinan adanya hambatan dan dukungan; dan (3) Kesiapan masyarakat setempat.

c. Pengembangan Ekonomi Masyarakat

Strategi pengembangan ekonomi dipengaruhi oleh beberapa faktor, yakni (1) faktor ketersediaan sumber daya yang ada di kawasan ini, baik sumber daya lokal (tanah, informasi, 
teknologi, energi,dan kreativitas) maupun sumber daya manusia, termasuk proses pengolahan sumber daya tersebut, (2) tingkat pendapatan dan pola konsumsi masyarakat, (3) faktor ketersediaan infrastruktur untuk produksi dan distribusi barang dan jasa, (4) faktor suprastruktur yang ada, yakni peraturan dan kebijakan pemerintah setempat, dan (5) faktor kondisis sosial-budaya. Bentuk spesifik dan konkrit yang dapat direkomendasikan adalah pengembangan ekonomi masyarakat berbasis potensi ekowisata.

Salah satu IPAL komunal yang ada di bantaran Sungai Code adalah di Cokrodiningratan RT 37 RW 08. Hasil survei kuesioner menunjukkan 99\% warga memanfaatkan IPAL komunal, hanya 1 KK yang diputus. Partisipasi besar dari warga ini selain kesadaran dan tuntutan lingkungan, juga faktor ekonomi dimana pembangunan dan pemasangan instalasinya dibiayai penuh pemerintah, sedangkan untuk operasionalisasi dan pemeliharaan hanya dikenakan iuran Rp. 2000/KK/bulan. Berdasarkan kondisi ini maka strategi penanganan pencemaran yang paling utama adalah menggerakkan partisipasi masyarakat hingga secara sistematis mengoptimalkan kelembagaan maupun komunitas lokal.

Salah satu pendekatan penting dalam pengelolaan sungai adalah penggunaan konsep communitybased development. Pembangunan berbasis masyarakat dapat dimaknai sebagai co-management (pengelolaan bersama), yakni pembangunan yang dilakukan oleh masyarakat bersama-sama dengan pemerintah setempat, yang bertujuan untuk melibatkan masyarakat lokal secara aktif dalam kegiatan perencanaan dan pelaksanaan suatu pembangunan dan pengelolaan. Community development adalah suatu upaya perubahan terencana (planned change) yang dilakukan secara sadar dan sungguh-sungguh melalui usaha bersama masyarakat untuk memperbaiki keragaan sistem kemasyarakatan (Chambers, 2006).

Pendekatan ini perlu ditempuh karena masyarakat lokal adalah orang-orang yang paling tahu kondisi sosial budaya setempat. Setiap kegiatan pembangunan harus memperhatikan nilai-nilai sosial budaya pembangunan. Setiap langkah keputusan perencanaan harus mencerminkan keaktifan masyarakat lokal yang ikut terlibat di dalamnya. Pelibatan masyarakat sejak awal akan lebih menjamin kesesuaian program pengembangan dengan aspirasi masyarakat karena adanya rasa memiliki yang kuat. Konsep pendekatan ini dalam jangka panjang akan memungkinkan tingkat kontinuitas yang tinggi. Pengembangan masyarakat lokal perlu didasarkan pada kriteria sebagai berikut (Law dan Hartig, J.H, 1993):

- memajukan tingkat hidup masyarakat sekaligus melestarikan identitas dan budaya lokal 
- meningkatkan pendapatan secara ekonomis sekaligus mendistribusikan merata pada penduduk lokal

- berorientasi pada pengembangan usaha berskala kecil dan menengah dengan daya serap tenaga besar dan berorientasi pada teknologi tepat guna

- mengembangkan semangat kompetisi serta koperasi

- memanfaatkan pariwisata seoptimal mungkin sebagai agen penyumbang tradisi budaya dengan dampak seminimal mungkin

Tata kelola sungai juga perlu melibatkan berbagai pihak: pemerintah daerah, akademisi dan masyarakat pinggir sungai sebagai pemangku. Dalam konteks community development, ada tiga hal yang perlu mendapat penekanan yaitu partisipasi publik, community education, dan keberlanjutan.

Banyak pihak memberi perhatian terhadap agenda pengelolaan Sungai Code, baik dari pemerintah, perguruan tinggi, masyarakat maupun kalangan LSM. Pada tahun 2003 tujuh perguruan tinggi di Yogyakarta telah membentuk konsorsium bagi pengelolaan kawasan sungai yang berada di Yogyakarta. Berbagai kelompok masyarakat lokal yang peduli Sungai Code juga telah bermunculan dengan membawa agenda masing-masing, misalnya Gerakan Cinta Code (GCC) di Suryatmajan, Team Komunitas Pinggiran Sungai (TKPS) di Gondolayu, Forum Masyarakat Code Utara (FMCU) dan Masyarakat Peduli Winongo di Badran. Beberapa komunitas telah berkoordinasi dalam Forum Pemerti Kali Code. Permasalahan mendasarnya adalah pihak-pihak terkait tersebut belum terkoordinasi secara terpadu dan program penataannya juga belum sistematis.

Masyarakat selama ini secara kreatif telah berinisiatif melakukan kegiatan, seperti upacara Merti Code, lomba kebersihan lingkungan, pembuatan jalan, juga tamanisasi pinggir sungai. Berbagai kegiatan, program, studi, dan aktivitas lainnya menyangkut pengembangan Sungai Code oleh beberapa pihak masih terkesan sporadis dan belum menyentuh sisi manajemen yang berkelanjutan.

Berdasar pada pola keruangan dan kecenderungan masyarakat yang terbiasa dengan kenyamanan dan komunalitas, maka pemberdayaan harus dilakukan dengan pendekatan yang tepat. Code sebagai kawasan wisata, Code sebagai laboratorium pengolahan air, dan kampung Code yang ditata Romo Mangun dan dilukis oleh para pembuat mural, sudah dilakukan dan memperindah kawasan ini. Kawasan Sungai Code membutuhkan perubahan budaya yang tentunya membutuhkan waktu dan membutuhkan bukti keberhasilan, yakni tercapainya kehidupan yang lebih baik. Posisi pedagang 
VCD, penjual burjo, atau pun karyawan toko membuat mereka terpatri pada aktivitas hariannya. Jika tidak ada kebutuhan untuk mencapai kehidupan yang lebih baik, maka masyarakat akan berkutat dalam rutinitas dan tidak memikirkan perubahan, karena perubahan berarti merubah tatanan yang terlanjur nyaman. Maka dalam hal ini, yang dibutuhkan adalah perubahan cara pandang, bahwa hidup bukan hanya untuk mendapat uang namun perubahan gaya hidup yang peduli dengan lingkungannya.

Proses perubahan sosial akan lebih efektif jika didorong oleh faktor dari dalam yang sering disebut sebagai immanent change, dimana perubahan dikarenakan oleh ditemukannya berbagai inovasi baru dalam masyarakat itu sendiri. Perubahan semacam ini tidak membutuhkan berbagai macam penyesuaian sosial masyarakat karena berasal dari masyarakat itu sendiri. Sementara itu, perubahan yang dikarenakan oleh berbagai program pembangunan dari luar masyarakat dan dibawa oleh agen pembangunan disebut sebagai direct contact change. Perubahan semacam ini membutuhkan berbagai macam penyesuaian, baik program yang ditawarkan maupun masyarakat penerima program.

Masyarakat Yogyakarta sangat menyukai simbol dan mencintai budaya. Budaya yang perlu ditanamkan perlu dilakukan secara simultan sejak dini dan didukung oleh keluarga dan contoh/role model. Role model ini bukan hanya dilihat dari tokoh formal, namun juga insan terdidik dari Sungai Code yang tergerak membangun kampungnya. Perubahan ini bisa dimulai dengan mengajak warga untuk melakukan perubahan, bahwa Yogyakarta merupakan salah satu tolok ukur kedewasaan di Indonesia. Sungai Code di Yogyakarta dapat menjadi role model bagi penataan sungai di Indonesia. Padatnya pemukiman di Sungai Code bukan menjadi halangan untuk melakukan perubahan gaya hidup dan etos kerja. Dan itu dimulai dari segala sisi, pemerintah, akademisi, lembaga swadaya masyarakat, dan masyarakat itu sendiri. Pemerintah tentu memiliki kuasa untuk melakukan penataan dan mengeluarkan kebijakan terkait penataan wilayah. Terlebih lagi komunitas dan lembaga sosial yang secara khusus menangangi pendidikan dan kesenian. Upaya ini dapat terus dilakukan bersama sehingga Sungai Code ke depan menjadi percontohan pengelolaan sungai di Indonesia dengan masyarakat sebagai aktor perubahannya. Pancingan dan dukungan dari luar tentu diperlukan untuk mempercepat proses ini.

Saluran komunikasi antar warga dan partisipasi hanya dapat dilakukan dengan proses institusionalisasi (pelembagan). Tujuan utamanya adalah menjaring pendapat dan usulan, 
melakukan klarifikasi, kategorisasi hingga verifikasi usulan, dan akhirnya melakukan langkahlangkah riil. Integrasi kekuatan dalam sebuah lembaga merupakan salah satu wujud masyarakat modern, dimana tatanan sosial mempunyai payung hukum serta langkah-langkah operasional berdasarkan planning yang jelas dalam menggapai tujuan. Berbeda dengan komunitas yang mempunyai sanksi sosial berdasarkan pranata tanpa tujuan "keuntungan" yang jelas. Sifat dari komunitas adalah komunal dengan mengandalkan pemimpin yang kharismatik, namun sering melupakan kapasitas intelektul. Hal ini yang diharapkan berkembang dengan terwujudnya lembaga untuk masyarakat Sungai Code.

Integrasi kekuatan di Sungai Code adalah modal sosial masyarakat Code untuk mengatur diri mereka sendiri, untuk mewujudkan wilayah sungai yang khas Yogyakarta. Wilayah sungai Code akan menjadi wilayah self design yang dapat di rekayasa masyarakat setempat sesuai budaya relasi manusia dengan Sungai Code itu sendiri. Komunikasi yang terbangun melalui lembaga nantinya diharapkan dapat menjadi social relationship menuju harapan-harapan seluruh warga Code atas perbaikan kehidupan yang berbasis pada lingkungan sungai. Oleh karena itu yang terpenting dari lembaga tersebut adalah pola komunikasi. Pola komunikasi inilah yang akan disepakati dengan terbentuknya lembaga masyarakat yang menaungi keseluruhan warga masyarakat yang ada dibantaran Sungai Code, apakah utara, tengah maupun selatan. Sebagai embrio telah terbentuk lembaga Forum Pemerti Kali Code, meskipun prinsip keterwakilan dan kelangkapannya masih belum memenuhi.

Kelembagaan yang ada nantinya harus benar-benar disepakati, mewakili kepentingan masyarakat, dan bersifat semi otonom. Kesepakatan dapat dilakukan dengan proses penjaringan aspirasi serta kordinasi antar komunitas yang ada, seperti unsut lembaga pemerhati, unsur pemerintahan, dan komunitas sosial budaya lainnya. Pelembagaan ini haruslah didukung oleh pemerintah daerah, oleh karena itu pembentukan lembaga disahkan dengan Surat Keputusan Walikota atau sejenisnya. Keberadaan AD/ART dan akte notaris juga mutlak diperlukan pada tahap berikutnya untuk memenuhi kelengkapan lembaga formal. Bagaimanapun proses pengorganisasian masyarakat, apalagi dalam skala cukup besar rentan terhadap potensi konflik sosial. Proses ini haruslah benarbenar berorientasi pada keterlibatan penuh masyarakat secara sistematis dan simultan.

Pengembangan komunitas lokal selain dipengaruhi kebutuhan dan aspirasi / kehendak publik lokal, juga tergantung oleh kebijakan publik pada herarki birokrasi lebih atas. Proses penguatan 
komunitas lokal dengan demikian tidak lepas dari kemauan politis pemerintah. Oleh karena itu, pemerintah dan legislatif harus benar-benar 'rela' memberikan keenangan pengelolaan melalui komunitas nantinya. Lembaga yang terbentuk harus menyentuh pada semua elemen (institusi) publik hingga level paling bawah dimana arah pengembangannya diorientasikan pada penguatan partisipasi masyarakat. Lembaga tersebut harus memenuhi keterwakilan pemerintah, swasta, dan unsur lainnya, namun porsi terbesar dan peran strategis tentu harus berada pada komunitas lokal.

Beberapa hal yang diperlukan dalam strategi pengembangan kelembagaan lokal, antara lain:

- Kesiapan pemerintah dalam pembangunan dan pengendalian, baik dari segi kebijaksanaan, dukungan personalia,anggaran maupun administratif.

- Kesiapan masyarakat setempat.

- Kesiapan pihak - pihak lain (swasta) dalam menghadapi kemungkinan adanya hambatan dan dukungan.

Berkaitan dengan hal tersebut di atas, pilihan strategi sudah seharusnya mempertimbangkan dan menyentuh pada tiga hal tersebut di atas. Dalam hal ini, pengembangan kelembagaan perlu dipertegas sebagai upaya untuk mengatur berbagai aspek agar dapat mengantisipasi berbagai hambatan dan benturan yang diperkirakan akan terjadi di masa datang.

Kelembagaan pada ranah formal juga perlu mendapat perhatian untuk dibenahi. Peran pemerintah yang terdiri dari Balai Pengelolaan Daerah Aliran Sungai Opak-Oyo-Progo di bawah Kementerian Kehutanan, Balai Besar Wilayah Sungai Serayu-Opak di bawah Kementerian Pekerjaan Umum, Dinas PUP-ESDM Provinsi DIY, Bappeda, Badan Lingkungan Hidup, dan Dinas terkait di bawah Pemerintah Provinsi dan Pemerintah Kabupaten/Kota dalam membangun kebersamaan menjadi sangat penting. Pemahaman terhadap peta kelembagaan di wilayah DAS Code diperlukan untuk melakukan analisis kelembagaan yang bertujuan untuk menentukan lembaga manakah yang paling tepat untuk melakukan Koordinasi, Intergrasi, Sinergitas, Sinkronisasi pengelolaan lingkungan di sub DAS Code . Penguatan kelembagaan diharapkan dapat mengoptimalkan peran aktif para pihak yang terkait dalam pengelolaan lingkungan di wilayah DAS Code. Kaitannya dengan pengendalian dan pengelolaan kualitas lingkungan, seperti air limbah, sampah, dan lainnya. 


\section{KESIMPULAN}

Hasil dan pembahasan di atas akhirnya memberikan kesimpulan sbb:

1. Pada inlet, konsentrasi $\mathrm{NH}_{3}$ melampaui baku mutu di semua titik, konsentrasi TSS belum melampui semua, dan COD yang sudah melampui antara lain di titik 2, 3, dan 8 .

2. Pada outlet, konsentrasi $\mathrm{NH}_{3}$ melampaui baku mutu di semua titik, konsentrasi TSS belum melampui semua, dan COD juga sudah melampui semua.

3. Konsentrasi limbah pada outlet lebih rendah daripada inlet antara lain untuk COD di titik 2, 3, 4, dan 8, TSS di titik 2, 3, 4, 5, 6, 11, dan 12 serta untuk NH3 di titik 2, 3, 4, 8, dan 9.

4. Sumber pencemar air di Sub DAS Code berjumlah sekitar 214 sumber pencemar.

5. Strategi teknis penurunan pencemaran limbah domestik antara lain dengan pengembangan dan optimalisasi IPAL komunal serta pengelolaan sampah terpadu.

6. Strategi sosial penurunan pencemaran limbah domestik antara lain dengan pemberdayaan masyarakat, penguatan komunitas lokal, serta optimalisasi kelembagaan formal.

\section{UCAPAN TERIMA KASIH}

Penulis ucapkan terima kasih kepada Direktorat Penelitian dan Pengabdian Masyarakat (DPPM) UII yang telah membiayai penelitian ini.

\section{DAFTAR PUSTAKA}

Balai Besar Wilayah Sungai Serayu Opak. 2008. Revitalisasi Sungai Code dan Anak Sungainya Provinsi DIY. Laporan Akhir Penelitian. Yogyakarta : BBWS Serayu Opak Departemen Pekerjaan Umum.

Chambers, Robert. 2006. Participatory Rural Appraisal : Memahami Desa Secara Partisipatif. Yogyakarta : OXFAM - Penerbit Kanisius.

Law dan Hartig, J.H. 1993. Public Participation in Great Lakes Remedial Action Plan. Plan Canada. March : 31-5.

Seyhan, Ersin, 1977, The Watershed as An Hydrologic Unit, Utrecht : Geografisch Instituut Rijkuniversiteit.

Widodo, 2005, Managing Water Resources in Yogyakarta Region, Germany : Kalsruhe University. 